Revue Française de Civilisation Britannique

\title{
The Conservatives: their Sweetest Victory?
}

Les Conservateurs : la plus douce des victoires?

\section{Tim Bale and Paul Webb}

\section{OpenEdition}

\section{Journals}

Electronic version

URL: http://journals.openedition.org/rfcb/480

DOI: $10.4000 / \mathrm{rfcb} .480$

ISSN: 2429-4373

\section{Publisher}

CRECIB - Centre de recherche et d'études en civilisation britannique

\section{Electronic reference}

Tim Bale and Paul Webb, "The Conservatives: their Sweetest Victory? », Revue Française de Civilisation Britannique [Online], XX-3 | 2015, Online since 01 December 2015, connection on 19 April 2019. URL: http://journals.openedition.org/rfcb/480; DOI : 10.4000/rfcb.480

This text was automatically generated on 19 April 2019

Revue française de civilisation britannique est mis à disposition selon les termes de la licence Creative Commons Attribution - Pas d'Utilisation Commerciale - Pas de Modification 4.0 International. 


\title{
The Conservatives: their Sweetest Victory?
}

\author{
Les Conservateurs : la plus douce des victoires?
}

Tim Bale and Paul Webb

1 Virtually nobody standing for, or working for, the Conservative Party at the general election of 2015 expected it to win an overall majority. True, there were those who were more bullish about the party's prospects than many of the pundits and pollsters who published their predictions in the week running up to the poll - but in most cases only to the extent that they believed that the Tories would emerge not just as the largest party (the consensus view of the forecasters) but with enough seats to make it likely that they could put together a minority government or else renew the coalition with the Liberal Democrats that had governed the country since May 2010.

Both Jim Messina, the veteran of the Obama campaign who David Cameron had brought in to advise the Tories on voter identification and mobilisation, and Lynton Crosby, the Australian consultant who was in overall charge of the Conservative campaign, were quietly confident by polling day itself that the party would win around 300 seats. But even they were pleasantly surprised at the exit poll. Even then, they didn't breathe easy until the result from marginal constituency of Nuneaton came in at 1.50am, showing that the Conservatives had increased their share of the vote by four percentage points, while Labour's had actually dropped. As more and more results came in, it became clear that the exit poll's projection had actually understated the Conservatives' margin of victory: Mr Cameron would be back as Prime Minister, but more than that - he would be heading a Tory government which, with 12 seats more than all the other parties in Parliament put together, would not need to rely on anyone else's help to run the country.

This, then, was a historic victory, achieved against expectations and in some ways in defiance of what are sometimes presented as the laws of political gravity. David Cameron is the first Prime Minister since Margaret Thatcher in 1983 to increase the number of Tory MPs in Parliament from one election to the next and the first Tory Prime Minister since Anthony Eden in 1955 to increase the party's share of the vote. The Tories won 330 
seats (51\% of the total) on a vote-share of $37 \%$ (just under one percentage point up from 2010). Just as encouragingly, albeit under the radar, they picked up around 500 additional seats in local government and assumed control of thirty more councils, which, given how often party activists these days are either elected representatives or their friends and relations, may help them at the next general election, currently scheduled for 2020 . They will also be advantaged at that election by boundary reforms which, according to some projections, could effectively give the Conservatives an extra twenty seats or so and mean Labour will need a swing as big as those achieved by Herbert Asquith in 1906 and by Clement Attlee in 1945 to win an overall majority next time around.

The Conservatives' improved performance was down in no small measure to what we might call «the black widow effect': after mating with their Liberal Democrat coalition partners, they gobbled them up, taking 27 of their seats. The Tories lost only 2 seats, net, to Labour, helped by an incumbency effect favouring Conservative MPs who won their seats in 2010, and, as we shall go on to suggest below, by being well ahead of Her Majesty's Official Opposition when it came to voters' views on which party would best manage the economy and which had the best leader. In this, they were almost certainly helped by their campaign, which much like the work done by Better Together before the Scottish independence referendum, could hardly be called pretty but turned out to be highly effective. Not only did it manage to focus relentlessly on Labour's negatives and neutralise any of its positives, it may also, via its emphasis on the 'chaos' inherent in some sort of Labour-SNP 'deal', have persuaded some who might otherwise have wavered ultimately to vote Tory. Possibly (although only partially) as a result, UKIP, contrary to much, but not all, conventional wisdom before the election, may well have done much, if not more, damage to Labour than to the Conservatives in some crucial English marginals.

\section{The long-term context: Conservative development, 1992-2010}

David Cameron, along with George Osborne, has taken the Tories a long way in the ten years since he became leader towards restoring their reputation as Britain's (or at least England's) "natural party of government". Indeed, it is easy to forget just how bad things had become back then. After presiding over the country's embarrassing and expensive exit from the Exchange Rate Mechanism (ERM) in 1992, thereby forfeiting public trust in its ability to run the economy, the Conservative Party turned in on itself over Europe and was subsequently swept away in the 1997 Labour landslide. Rather than coming to their senses, however, the Tories headed for the ideological hills, selecting a series of frankly unelectable leaders and pursuing policies (or at least, adopting a rhetoric and tone) that looked a long way out of step with where most of the electorate located themselves. ${ }^{1} \mathrm{By}$ their third defeat in a row in 2005, it had become obvious, even to many die-hard rightwingers, that things would have to change - or at least be made to look as if they had changed.

6 Cameron, who offered himself as the proverbial "change candidate" appeared to many (even to some of those who couldn't bear his incipient sense of entitlement and his claim to stand on the pragmatic centre-ground) to be the answer to the party's prayers: Eurosceptic without being obsessive, Thatcherite without being a zealot, and a gifted communicator - a politician not only able to convey genuine enthusiasm for national 
treasures like the NHS but to look like he was at home in the more socially liberal, ethnically-diverse country that twenty-first century Britain had become. His game plan, however, was rather more complex than some of his right-wing detractors and some of his left-wing and socially liberal admirers gave him credit for. He and other "modernisers" clearly believed that the Conservatives must do all those things that Conservative oppositions (including the one led by Margaret Thatcher between 1975 and 1979) had done to put the party back in contention. Rather than obsessing over issues which fired up the party faithful but put off large numbers of voters - especially many liberal middleclass voters who ought otherwise to be Tory supporters - the party should focus counterintuitively on topics, such as the environment, that would symbolise a shift away from its past. And it should insist that those parts of the welfare state which (like it or not) enjoyed overwhelming public backing, such as the NHS, education and pensions, were completely safe in the new leadership's hands.

7 "Team Cameron", however, did believe in a smaller role for the state and that the public could be convinced, pace New Labour, that tax cuts and spending reductions wouldn't automatically lead to reductions in public services. They just believed that the place to persuade people was in government rather than out of it. Unfortunately for them, however, things did not go entirely according to plan. Gordon Brown's decision not to call a snap election in the summer of 2007 was followed by a chapter of accidents and then the global financial crisis. All of this boosted Tory fortunes but effectively put the brand decontamination operation on ice, meaning that the lead which the Conservatives had built up over the next year or two was more fragile than it looked. By May 2010, as the economy began to recover and doubts about the Conservatives' good intentions began to resurface now that Cameron and Osborne were talking about "an age of austerity", a double digit Tory lead at the end of 2009 had dropped into single figures - so narrow that even a brilliant short campaign would have had trouble getting Cameron over the line - at around 323 seats - for an overall majority. And sadly for him, the Tory campaign, although incredibly well financed and equipped (at the national level at least) with what was then state-of-the-art technology, turned out to be anything but brilliant. Little wonder perhaps that the British Election Study's panel study found that the Tories ended up with less support at the end of the short campaign than they had at the beginning. ${ }^{2}$

As a result, the Tories had fallen short - their lead on "instrumental" evaluations associated with "valence politics", namely relative judgements about leadership, credibility and competence, was enough to make them the largest party in a hung parliament but was insufficient, given lingering concerns about their real intentions towards public services and how much they had really changed, to afford the party the overall majority that some Conservative MPs had assumed would be theirs. ${ }^{3}$ Some of those MPs were even more alarmed at what happened next. Faced with a Liberal Democrat leadership which was some way to the right of the majority of their party, but who clearly were not going to be content with simply supporting a Conservative minority government, Cameron offered Clegg a full-blown majority coalition. Given that Labour could not match that offer, it is understandable that it was accepted. But what defies understanding is the Liberal Democrats' failure to negotiate an agreement, be it on policy or on portfolios, which might have given them a sporting chance of claiming credit for what the government they had joined would go on to do. Little wonder that William Hague, former Tory leader and future Foreign Secretary returned from the negotiations and declared " $I$ think I've killed the Liberal Democrats". ${ }^{4}$ 


\section{The Permanent Campaign: 2010-2015} leadership immediately co-opted them into what was a ruthless and highly effective campaign to re-write history and, in so doing, destroy Labour's reputation for economic competence. Years of uninterrupted growth after 1997 had allowed Labour to build up a big lead on the issue and, while that lead had been lost during the banking crisis, the party had been closing on the Conservatives again as the economy began to recover in the months leading up to the election. Now, however, it was involved in a leadership contest in which even the most Blairite of the candidates spent most of their time insisting on the need to move beyond New Labour rather than the importance of defending its record and its achievements. Seizing the opportunity provided by this hiatus - and by an emergency budget supposedly designed to ensure that Britain did not go the way of Greece - Osborne and Cameron (assisted by Liberal Democrat politicians desperate to persuade their erstwhile supporters that they had gone into coalition to protect what they insisted was " the national interest"), rammed home the message that Labour had, in their words, "maxed out the nation's credit card" and "failed to fix the roof while the sun was shining", thereby giving the impression that "the mess" they were having to clear up was due not so much to a global crash as to Blair and Brown's supposed profligacy and mismanagement. This was enough to ensure that even when, as Shadow Chancellor Ed Balls predicted, the Coalition's austerity programme damaged (or at least delayed) the recovery, Labour was unable to capitalise on its temporary distress. Labour's difficulties in turn meant that when the economy at last began to grow again, after Osborne quietly took his foot off the brake, the Conservatives were able to contrast the Coalition's performance with a caricature of what had happened between 1997 and 2010 that was by then deeply embedded, namely the idea - hotly disputed by many economists, who point out that the sums involved were inconsequential, both in relative and absolute terms - that Labour had "overspent" and run a deficit even when the economy was doing well. That narrative, and of course the recovery itself - even though it was not accompanied by the kind of sustained rise in real wages needed to generate a "feel-good factor" - ensured that, by the time the 2015 election came round, the Tories led Labour as the best party to handle the economy by some twenty percentage points.

Cameron and Osborne were also ruthless, perhaps even more so, in exploiting Labour's other big weakness - the widespread perception that it was a soft touch on welfare. Given the hyperbole that characterised tabloid newspapers' coverage of the issue, their readers could be forgiven for thinking that almost everybody claiming benefits was either doing so fraudulently or as a foreigner, or both - when, that was, in the very worst tabloid case, they weren't busy breeding and then killing their own children. ${ }^{5}$ Naturally, official statements or ghosted columns put out in the name of government ministers, were generally more careful and coded, with Osborne's headline-grabbing response to the Mick Philpott case perhaps the paradigmatic example. ${ }^{6}$ They nonetheless constituted a concerted and effective effort, exploiting long-established and popularly-held distinctions between the "undeserving" and the "deserving" poor, to justify money-saving policy changes by giving the impression that the only losers would be people currently getting "something for nothing" - the shirkers and skivers rather than the workers and the strivers. Because it was almost bound to stick up for those who stood to lose out, Labour 
could then be portrayed as a budget-busting friend of the feckless, with any outrage expressed on its part at the shocking unfairness of the stereotypes involved simply playing into Osborne's hands by giving legs to all the stories that helped reinforce those stereotypes in the first place. And when Labour belatedly tried to go the other way and attempted to "out-Osborne Osborne" by making some supposedly "tough choices" of its own on welfare, it was too late to convince voters it was sincere and probably did no more than legitimize and perpetuate the myths that played so well for the Conservatives in the first place.

11 Of course, the Conservatives didn't have everything their own way. They failed, because of a bust-up with the Liberal Democrats over Lords reform, to achieve a reduction in the size of the Commons that would have prompted a boundary review estimated to be worth around twenty additional Tory seats. And on one issue, immigration, which, since the mid-1960s, has been one of their most reliable weapons in their electoral battles with Labour, they struggled to maintain credibility. A rash pledge in the run up to the 2010 election that a Tory government would reduce net immigration from the EU from hundreds to tens of thousands backfired when, despite legislation and rule changes designed to "crack down", the figure actually rose markedly over the course of the Parliament. True, it was UKIP rather than Labour which benefited most from this all-tooobvious failure, despite Miliband shifting his party's stance on the issue to a more restrictive one from 2011 onwards. ${ }^{7}$ Nevertheless, the Tories' lead over their main opponent shrank, according to YouGov's tracker on best party to handle immigration and asylum, from 28 points ( $45 \mathrm{vs} \mathrm{17)} \mathrm{in} \mathrm{May} 2010$ to just six points (22 vs 16) on the eve of the general election in May 2015. Meanwhile, on Europe - where Conservatives have also come to assume that they enjoy an advantage over Labour in these increasingly Eurosceptic times - their position was far from strong: certainly any hope that Miliband's decision not to match Cameron's offer to hold an in-out referendum would damage him proved forlorn - possibly because it was obvious to the electorate that the offer was only made in order to appease Eurosceptic backbenchers worried about UKIP. The story on health (traditionally Labour's strong suit) was not quite as bad, but the issue nonetheless remained a problem - and was made worse when the government went ahead with legislation in 2011-12 that totally contradicted their pre-election promise to avoid a "topdown reorganisation" of the NHS. Prior to the legislation being announced, the Tories had actually reduced Labour's lead on the issue to one or two percentage points. After the announcement, Labour's lead went back into double figures and, prompted, too, by rising waiting times, hospital deficits, and local closures, pretty well stayed there until polling day in 2015.

\section{The Short Campaign: March-May 2015}

To understand why the Conservatives fought the campaign of 2015 the way they did, one has to go back to the Conservative campaigns of 2005 and 2010. The latter was widely perceived, not least by those working at Conservative Campaign Headquarters ( $\mathrm{CCHO}$ ), as a bit of a mess. Its untested main theme - the Big Society - not only failed to impress, but was a distraction. Meanwhile nobody was ever quite sure exactly to whom they were reporting and who had the final word. What a contrast with 2005, when at least everyone knew who was running the show - the so-called Wizard of Oz, Lynton Crosby - and the 
result, while dire, was a marked improvement in terms of seats, on the two previous contests.

Campaign 2015, then, would be the safe if dull one in which Cameron looked and sounded like a Prime Minister sticking to the game-plan devised by the fabled Australian who was supposed to know what he was doing. Cameron, having decided, along with George Osborne, on the basic strategy - banging on about fears on the part of "business" about a Labour government; donning hi-viz jackets and hard-hats to emphasise their "long term economic plan" for "hard-working families"; counter-posing Conservative "competence" with Labour "chaos"; talking up the SNP "threat" while simultaneously portraying them as bullies and blackmailers; and badmouthing Miliband as a weak and weird individual whose only decisive act had been to shaft his own brother - left the tactics to the hired help. This, along with the fact that Cameron refused to risk a one-on-one television debate with Labour's leader and confined his public appearances to carefully-crafted pseudo-events, attracted more brickbats than plaudits - and some concerns even within the Prime Minister's own camp. The Tory leader's response to such criticisms, however, was essentially limited to rolling up his sleeves at his photo-ops to show how "pumped" he was and how hard he was working. Other than that, he simply stuck with the programme, reminding journalists that this was "the most organised, disciplined, clear campaign I have ever been involved in". ${ }^{8}$

There were few surprises, then, but there were some raised eyebrows. In particular, the decision to announce, at the same time as continuing to pound away at Labour's purported profligacy, that a Conservative government would guarantee billions of additional spending on the NHS, without actually identifying where the money would come from, was seen as a rather desperate move to prevent Labour from getting as much traction on health as it hoped. Desperate or not, it may well have done the trick. And the fact that it could be defended on the grounds that the Tories were good for the money because, unlike Labour, they could be trusted to grow the economy, was testimony to the unassailable lead they had built up on the latter - one that meant they felt able to ignore suggestions that they should somehow match Labour's promise to tax "non-doms" and raise the top rate of income tax to 50p, both policies being intended to tap into the widespread feeling (reinforced by the so-called omnishambles budget of 2012) that the Conservatives were "out of touch" and "the party of the rich".

Clearly, the leadership decided there was little point in wasting time trying directly to counter such deeply-held prejudices. Instead, they countered with some prejudices of their own, using highly supportive newspapers - especially the Sun ("This is the pig's ear Ed made of a helpless sarnie. In 48 hours, he could be doing the same to Britain"), the Mail ("For sanity's sake don't let a class-war zealot and the SNP destroy our economy - and our very nation"), and (to the embarrassment of some of their staff) the Telegraph ("Nightmare on Downing Street") and the Times - to ramp up fears of a Miliband-Sturgeon deal and to remind the public (if they needed reminding) of Ed Miliband's shortcomings as a leader. ${ }^{9}$ The party also used the press, especially in the last week of a campaign when it, like everyone else, firmly believed that the country was heading for another hung parliament, to question the legitimacy of any possible attempt by Labour, if it finished behind the Conservatives in terms of seats, to form a government.

16 Perhaps the least-noticed aspect of the Conservative campaign, however, was the decision, taken late in 2014, that, rather than focusing solely on the constituencies they needed either to defend or snatch from Labour while going easy on their coalition 
partners, the Conservatives would throw a significant proportion of their considerable financial resources at trying to unseat Liberal Democrats - an effort that gathered pace during the campaign when frontbenchers were dispatched to seats few had imagined were in play. Even then, the Tories' target seats coordinator, Stephen Gilbert, forecast that the Liberal Democrats would win around 15 seats - which was way below most pundits' guesses but, as it turned out, was almost twice as many as the eight that Nick Clegg's party finally ended up with. Clearly, the fact that the Conservatives took 27 seats from their erstwhile partners was due mostly to the Liberal Democrats losing an average 21 percentage points in seats they held by less than ten points from the Tories in 2010. But it also had something to do with the fact that Tory candidates in those seats managed to add an average of nearly 4 percentage points to the vote the party received at the previous election.

This points to the main reason (apart of course from winning all those Liberal Democrat seats) why the Conservatives were able to win an overall majority in spite of the fact that Labour actually managed to improve its share of the vote marginally more than they did. For the first time in a long time, the Tories managed to concentrate their vote in exactly the right places better than Labour did. In both safe Conservative and safe Labour seats, the Tories actually slipped by an average of two percentage points compared to 2010. In those marginal seats they were defending against Labour, however, they increased their average share by two points, while Labour managed to increase its share by, on average, less than two points. That said, given that Conservative candidates in Labour-held marginals did not in the main significantly increase their share of the vote, the main reason they were able to make eight gains from Labour (to offset their ten losses) may well have been down to some of the Labour vote going to UKIP. The fact that the nearly fourfold increase in the share of the vote won by Nigel Farage's party did not damage the Conservatives as much as expected, especially given that far more of its voters had previously supported the Tories than Labour, was remarkable. It is perhaps a testament to the effectiveness of the "coalition of chaos" strategy that many of them seem to have ended up sticking with the Conservatives for fear of letting in Miliband and/or the SNP. In any case, the SNP surge played an obviously important role in decimating Labour representation north of the border, while inflicting no damage on the Tories there - a major advantage for the Tories, although in the event they would have won an overall majority even if Labour had maintained its habitual dominance over the Scottish seats.

\section{Why the Conservatives won: post-election polling evidence}

18 Although the Conservatives enjoyed a remarkable victory, one thing seems fairly clear: it was not because of any great love on the part of the British electorate for the party or an affinity to its perceived values or ideology. According to British Election Study data gathered shortly before the campaign started, ${ }^{10}$ Labour just about retained its place as the most popular party in terms of partisan identification, with $27.8 \%$ of respondents claiming to identify with it (down from $31 \%$ in 2010 ), compared to $26.1 \%$ for the Conservatives (down from 27.1\%), and 6.2\% for the Liberal Democrats (15.9\% in 2010). Neither was the Conservative Party especially well liked, with an average score of just 3.77 on a scale running from 0 ("dislike") to 10 ("like"), compared to 4.12 for Labour and 3.02 for the Liberal Democrats; UKIP (5.10), SNP (3.94) and the Greens (3.98) all scored 
more highly than the Tories on this scale. Moreover, the BES data shows that the Conservatives were regarded as being more ideologically remote from the average voter than most other parties: the mean position of voters on a scale running from 0 ("very leftwing") to 10 ("very right-wing") was almost exactly in the centre, at 4.99, while the Tories and UKIP were both perceived as being well to the right of this position (at +2.93 and + 2.94 respectively), whereas the other main parties were all regarded as being to the left of the average voter - and all were seen as closer than the two right-wing parties; the Liberal Democrats were closest (at -0.21$)$, followed by SNP (-1.42), Plaid Cymru (-1.69), Labour (-1.87) and the Greens (-2.06).

The limited post-election polling evidence that is available at the time of writing suggests that the same factors that ushered the Conservatives into government in 2010 counted in their favour once again in 2015: perceived economic and leadership competence. ${ }^{11}$ Interestingly, post-election data published by Lord Ashcroft shows that the modal response to the question of which was the most important issue in 2015 was the NHS rather than the economy - and this held regardless of whether or not respondents were asked to consider their own family's position (58\%) or the country's position as a whole (55\%). ${ }^{12}$ One would normally expect it to favour Labour when the NHS is so salient - and indeed, there was some mileage in this issue for Labour; $76 \%$ of those voting Labour cited health as the most important issue for the UK, whereas only $39 \%$ of those voting Conservative did. Even so, close behind the NHS in terms of salience was the need to "get the economy growing and creating jobs" (51\%), and $61 \%$ of those citing this as one of the three most important issues voted Conservative, while only 50\% voted Labour. More directly telling, perhaps, is the fact that $46 \%$ of respondents (a plurality) agreed with the statement that "the national economy is not yet fully fixed, so we will need to continue with austerity and cuts in government spending over the next five years", including $84 \%$ of those who voted Conservative; by contrast, only $17 \%$ of Labour supporters saw things this way, as did $45 \%$ of Liberal Democrat supporters.

20 Further support for the argument that valence considerations weighed decisively in the balance is provided by a Greenberg Quinlan Rosler post-election poll that was commissioned by the TUC. ${ }^{13}$ This shows that the top three reasons for supporting the Conservatives were the feeling that the economy was recovering (39\%), that progress that had been made with deficit-reduction (29\%), and the belief that David Cameron would make a better Prime Minister than Ed Miliband (18\%). It is not necessarily that voters were entirely sold on the detail of economic policy: The GQR poll showed that fewer people agreed with the Conservative position that the best way to get the economy growing would be to get the deficit under control and cut taxes and red tape (43\%) than with the Labour emphasis on ensuring that "working people feel better off and more comfortable spending" (48\%). Nevertheless, $40 \%$ felt that Labour would "spend too much and can't be trusted with the economy", and $25 \%$ felt they would make it "too easy for people to live off benefits". A quarter also felt that Labour in government would be "bossed around by Nicola Sturgeon and the Scottish Nationalists", which suggests that the Tories' negative campaigning on the theme of a Labour-SNP "threat" may have resonated with a significant number of voters. More generally, far more respondents saw the Tories as competent (53\%) and having a good track record in government (50\%) than Labour, for whom the respective figures were only $29 \%$ and $25 \%$.

21 For the second election running David Cameron proved a huge asset to his party's electoral prospects. The Ashcroft poll showed that some $71 \%$ of Tory voters cited the 
leader as one of the three most important reasons for voting for the party, compared to just $39 \%$ of Labour voters. This is a very striking difference, which is consistent with the possibility that more and more voters are coming to rely on leadership evaluations as a heuristic simplification to guide their decision at a time when policy debates are becoming increasingly complex and almost impossible for non-experts to adjudicate on. ${ }^{14}$

While these valence considerations certainly mattered at the level of the individual voter, one other thing should not be overlooked in seeking to understand the unexpected Tory majority in 2015: the paradoxical impact of Liberal Democrat losses to Labour, of which the Tories were a serendipitous beneficiary. While disgruntled Liberal Democrat voters from 2010 probably shifted predominantly to Labour, this almost certainly ended up helping the Conservatives in terms of overall seat gains. The last BES pre-election panel showed $27 \%$ of the 2010 Liberal Democrats saying that they were intending to shift to Labour at the general election, while only $11.2 \%$ were planning to vote Conservative. Moreover, in the seats that the Liberal Democrats were defending in 2015, the Conservatives lost $0.5 \%$ of their vote on average, while Labour increased by $2.7 \%$. However, this profited Labour relatively little, given that in 33 of the 57 seats that the Liberal Democrats were defending, their nearest challengers were the Tories, compared to only 17 in which Labour were the main opponents. Thus, by taking Liberal Democrat votes, Labour's electoral progress in such seats more often than not only served to let the Conservatives win.

One final observation about the electoral standing of the Tories should be made, which takes us back to the point about the party not being especially loved by voters, notwithstanding the majority it secured in the Commons. It is clear that the Conservatives continue to have some significant image problems, which may hinder them in the next parliament. The GQR poll shows that the number one doubt voters have about the Tories is that "they are for the rich and powerful, not ordinary people" (36\% expressing this view). Not far behind (32\%) is the feeling that "they can't be trusted with the NHS" (the most salient issue at the election, remember), while a mere $29 \%$ of voters regarded them as "honest". This suggests a picture in which the nation has entrusted the government of the country to the Conservatives while having their eyes wide open as to the deficiencies of the party. To put it differently, the Tories may not have a strong bank of political capital on which to draw when the going gets tough in the years leading up to 2020 - as it almost certainly will, given the challenges to be faced over continuing economic recovery, and the UK's political relationships both internally and with the EU.

\section{Conclusion}

Speaking just after he realised he had won, David Cameron called 2015 his "sweetest victory ". But, as many commentators rushed to remind him, it has the potential to turn very sour very quickly. His narrow, 12-seat majority is smaller, it is worth recalling, than the 21-seat majority won by John Major (on $42 \%$ of the vote) back in 1992. Moreover, anyone old enough to remember that time will recall how that victory soon turned to ashes as Britain's "Black Wednesday" exit from the Exchange Rate Mechanism, the announcement of massive job losses in the coal industry and parliamentary rebellions over the Maastricht Treaty, turned him from hero to zero. It is difficult at present to foresee anything on the immediate economic horizon that could do such dramatic damage to the Tories' valuable reputation for competence in that sphere, although the severity of the 
expenditure cuts promised by George Osborne certainly has the potential to tip the economy into recession yet again. However, an arguably chronic tendency toward ideological overreach and internal strife over Europe means that Mr Cameron's successor, presuming he makes good on his promise not to seek another term, needs to be careful not to assume that he or she has the next general election in the bag. He has laid the foundations, but they need to be built on - and, given the cagey and contingent nature of the support given to the Conservatives by many of those who voted for them in May 2015, that building will have to be erected on the centre-ground of British politics rather than the cloud-cuckoo land inhabited by some of David Cameron's less pragmatic colleagues. Still, for all the dangers coming down the line, we should acknowledge Cameron's achievement. As the respected political commentator, John Rentoul, put it a few days after the election, "Overnight, he has transformed from the one-term mechanic called round to fix the deficit, who couldn't even do that, into a 10-year prime minister who can stamp his personality on the nation". ${ }^{15}$

Cameron may be helped to do that by a Conservative Party that is at last beginning to look a little bit more like the country it governs. The willingness of at least some constituency associations to pick (without being pressured to do so) less conventional Conservative candidates in safe or at least winnable seats means that the Tory benches in the Commons now contain the party's highest ever proportion of women, the 68 female MPs who sit there making up $21 \%$ of the party's contingent in the lower house. The Tories also have the largest number of non-white MPs they have ever had: a total of 17, seven of whom are new entrants to the Commons. In addition, «only' $48 \%$ of Tory MPs went to independent schools (with $34 \%$ having been to comprehensives and $18 \%$ to grammars), although this hardly constitutes proportional representation, given that only seven per cent of pupils currently go to schools outside the maintained sector; it is a drop from the 54\% who had been privately educated in 2010 and continues a long-term trend toward more state-educated Tory MPs. That said, a disproportionate share of the majority of Tory MPs who are graduates attended elite universities: some $34 \%$ of Conservatives in the Commons were educated at Oxford or Cambridge. If David Cameron was serious when he talked in the wake of his victory about the Tories becoming "the party of working people", then, in this respect at least, he still has a long way to go.

\section{BIBLIOGRAPHY}

BALE, Tim. The Conservative Party from Thatcher to Cameron. Cambridge: Polity, $3^{\text {rd }}$ edition, forthcoming.

D’ANCONA, Mathew. In it Together. London: Penguin, 2014.

GEDDES, Andrew \& TONGE, Jonathan. Britain Votes 2015. Oxford: OUP, 2015.

KAVANAGH, Dennis \& COWLEY, Philip. The British General Election of 2015. London: Palgrave Macmillan, 2015. 
SELDON, Anthony \& SNOWDON, Peter. Cameron at Ten: the Inside Story. London: William Collins, 2015.

\section{NOTES}

1. T. QUINN, 'The Conservative Party and the centre ground of British Politics', Journal of Elections, Public Opinion and Parties, vol. 18, $\mathrm{n}^{\circ}$ 2, 2008, pp. 179-199.

2. For a detailed look at 2010 based in part on BES findings, see J. GREEN «Strategic Recovery? The Conservatives under David Cameron', Parliamentary Affairs, vol. 63, $\mathrm{n}^{\circ}$ 4, 2010, pp. 667-688.

3. See T. BALE \& P. WEBB, «The Conservative Party' in N. ALLEN \& J. BARTLE (eds.), Britain at the Polls 2010, London: Sage, 2010, pp. 37-62.

4. Quoted in G. PARKER, «Highs and lows of the UK's coalition government', Financial Times, 26 March 2015. The most comprehensive sources on the Coalition include M. D'ANCONA, In It Together: The Inside Story of the Coalition government, London: Penguin, 2014; A. SELDON \& M. FINN (eds.), The Coalition Effect, 2010-2015, Cambridge: Cambridge University Press, 2015; and M. BEECH \& S. LEE, The Conservative-Liberal Coalition: Examining the Cameron-Clegg government, Basingstoke: Palgrave, 2015.

5. This was essentially the implication of the coverage of the genuinely shocking trial of one benefit claimant who, with two accomplices, was found to have burned down his house with some of his children still inside. See «Vile product of welfare UK', Daily Mail, 3 April 2013 (http:// www.dailymail.co.uk/news/article-2303120/Mick-Philpott-vile-product-Welfare-UK-Derby-manbred-17-babies-milk-benefits-GUILTY-killing-six.html), accessed 11 September 2015.

6. For Osborne's reaction when quizzed by a reporter about Philpott, see http://www.bbc.co.uk/ news/uk-22024061, accessed 11 September 2015.

7. T. BALE, «Putting it right? The Labour party's big shift on immigration since 2010', Political Quarterly, vol. 85, n³ 2014, pp. 296-303.

8. J. FORSYTH and F. NELSON, "David Cameron: 'I always manage to portray a calm smoothness or something'”, The Spectator, 25 April 2015 http://www.spectator.co.uk/features/9507922/whydont-people-think-you-want-to-win-prime-minister-i-dont-know-there-is-something-about-me/ 9. See J. JEWELL, «Election coverage: sweet victory or a new low for UK press?', 9 May 2015 https://theconversation.com/election-coverage-sweet-victory-or-a-new-low-for-uk-press-41569 10. We are grateful to the directors of the BES for making Wave Four of their panel data available for this analysis.

11. See T. BALE \& P. WEBB, «The Conservative Party' in N. ALLEN \& J. BARTLE (eds.), Britain at the Polls 2010, London: Sage, 2010, pp. 37-62.

12. See http://lordashcroftpolls.com/wp-content/uploads/2015/05/LORD-ASHCROFT-POLLSPost-vote-poll-summary1.pdf

13. See http://www.gqrr.com/uk-post-election-3.

14. See A. BITTNER, Platform or Personality? The Role of Party Leaders in Elections, Oxford: Oxford University Press, 2011; G. EVANS \& R. ANDERSEN, «The impact of party leaders: How Blair lost Labour votes' in P. NORRIS \& C. WLEZIEN (eds.), Britain Votes 2005, Oxford: Oxford University Press, 2005; M. COSTA LOBO \& J. CURTICE (eds.) Personality Politics? The Role of Leader Evaluations in Democratic Elections, Oxford: Oxford University Press, 2014.

15. J. RENTOUL, «Is no one going to give Cameron any credit?' Independent on Sunday, 10 May 2015. 


\section{ABSTRACTS}

In the 2015 general election, the Conservative party did not just win an overall parliamentary majority against expectations, but they also increased their national share of the vote and secured additional seats in local government. The article examines the long and short term campaigns and contrasts the 2010 campaign with the one in 2015 to explain their success. It highlights how the Conservatives were able to spin a convincing narrative of Labour economic incompetence and welfare profligacy and capitalise on their opponents' inner conflicts and voters' fears of a Labour-SNP coalition. The article argues that their victory is also due to their command of valence issues and their effective targeting of marginal seats.

Lors des élections parlementaires de 2015, le parti conservateur n'a pas seulement remporté une majorité absolue de sièges au Parlement contre toute attente mais a également accru sa part nationale des voix et gagné de nouveaux sièges au niveau local. Cet article revient sur la campagne courte et la campagne longue des Conservateurs et oppose la campagne de 2010 à celle de 2015. Il souligne combien le parti est parvenu à tisser un récit convaincant des années Labour, arguant de l'incompétence économique de ses opposantes et de leur prodigalité excessive en matière de dépenses sociales, tout en exploitant leurs conflits internes et la crainte des électeurs d'une alliance SNP-Labour. L'article revient sur leur domination de certains sujets électoraux et leur stratégie pour cibler certains sièges.

\section{INDEX}

Keywords: Conservatives, Cameron, elections, Tory, United Kingdom

Mots-clés: conservateurs, Cameron, élections, Tory, Royaume-Uni

\section{AUTHORS}

\section{TIM BALE}

Queen Mary University

PAUL WEBB

University of Sussex 